\section{FLOR DE OTOÑO: EXAMPLE OF PLAY ADAPTED TO FILM BEFORE REACHING THE STAGE}

\author{
Phyllis Zatlin \\ Dept. of Spanish \& Portuguese \\ Rutgers, The State University of New Jersey \\ 105 George St. \\ New Brunswick, NJ 08901-1414, USA \\ zatlin@rci.rutgers.edu
}

\section{FLOR DE OTOÑO: EJEMPLO DE UNA OBRA DE TEATRO ADAPTADA A UNA PELÍCULA INCLUSO ANTES DE SER REPRESENTADA}

\begin{abstract}
RESUMEN: En general, la adaptación filmica de obras de teatro suele poner de manifiesto tensiones entre la fidelidad a puestas en escena previas y el deseo de evitar el "teatro enlatado". Menos frecuente es el caso de una cronología inversa como el representado por Flor de Otoño, de José M. ${ }^{a}$ Rodríguez Méndez, en el que un texto escrito para el teatro llega antes al público de cine. Escrita en 1972, la pieza de Rodríguez Méndez no se estrena hasta 1982, después de pasar por la pantalla en una adaptación fílmica dirigida por Pedro Olea en 1978. El análisis de esta versión cinematográfica de una obra teatral se detiene en las estrategias adaptativas que moviliza a la vez que considera la ausencia de puesta en escena previa como una solución que favorece la libertad creativa en dicho proceso.
\end{abstract}

PALABRAS CLAVE: Adaptación fílmica; metateatralidad; Pedro Olea; José M. ${ }^{a}$ Rodríguez Méndez; teatro representado.

The transformation of stage plays into film is a subject that has given rise to varying points of view over the years, ranging from the total rejection of what is pejoratively termed "canned theatre" to total acceptance of the relationship between the genres. Maria Asunción Gómez suggests that it is harder to adapt plays than novels for the screen; while the latter require a shift from a verbal narrative mode to a visual one, "para convertir una acción dramática en una narración, se requieren cambios sustanciales" (Gómez, 2000, 51). A more prevalent viewpoint, however, is that of director Josefina Molina, who considers theatre and film to have a symbiotic relationship: "al igual que el cine ha influido en el teatro y éste en el cine, son realmente como vasos comunicantes" (Molina, 1981, 29).

In a similar vein Ángel Luis Hueso observes: "Reflexionar sobre el cine y el teatro (o el teatro y el cine, dado que en ambas direcciones se produce una intensa

\begin{abstract}
Film adaptation of plays generally reveals tension between fidelity to previous stage performances and desire to avoid "canned theatre". Less common is the reverse chronology when a text, written as a stage play, is made into a movie before it reaches theatre audiences. An example of this exception is Rodríguez Méndez's Flor de Otoño. Written in 1972, Rodríguez Méndez's play was not staged until 1982. In 1978, it was made into the movie, Un hombre llamado Flor de Otoño, directed by Pedro Olea. Our analysis of this film version of a play script considers how it follows anticipated adaptation strategies and whether the absence of prior stage performances facilitated greater freedom in the process.
\end{abstract}

KEY WORDS: Film adaptation; metatheatricalism; Pedro Olea; José M. ${ }^{a}$ Rodríguez Méndez; stage play.

relación) es uno de los aspectos más sugestivos cuando se intentan comprender los complejos ámbitos con que se desarrolla la imagen animada" (Hueso, 2001, 45). Teresa García-Abad García agrees, concluding that influence of film on modern theatre has been beneficial (Garcia-Abad, 1997, 481). In his book Cine y literatura, first published in 1985, Pere Gimferrer underscores the importance of dialogue and affirms, with specific examples, "nadie consideraría hoy un elemento negativo la 'teatralidad' de las películas de Eric Rohmer o Jacques Rivette" (Gimferrer, 2005, 92). Building on Gimferrer's work, Juan A. Hernández Les states, "De todos los orígenes posibles, quiza sea el teatro el que mejor se adapta a las habilidades cinematográficas"; the reason, he clarifies, is that "cine adapta del teatro una forma de expresión más que un relato, mientras que adapta de la novela un relato más que una forma de expresión" (Hernández Les, 2005, 130). 
Comments on the relationship of screen adaptations of stage plays assume that the texts in question have in fact been produced, as has generally been the case with the innumerable plays that have been made into movies. The extensive list that Gómez provides of filmic transformations of Spanish plays from 1907 to 1996 establishes that cinematic adaptation of successful stage plays is common (Gómez, 2000, 198-217), but it is quite rare for a play script that was expressly intended for legitimate theatre to reach the screen first. If a film version is created from a written text that has not yet been performed, does that circumstance change the director's stance? That is a question posed here for José Maria Rodríguez Méndez's Flor de Otoño.

Rodríguez Méndez's highly metatheatrical play was written in 1972 and published in the theatre journal Primer Acto in 1974; in part because of problems with censorship, it was not staged until 1982. In 1978, it was made into the movie Un hombre llamado Flor de Otoño (dir. Pedro Olea, filmscript by Rafael Azcona and Pedro Olea). At the time of its writing, the author lived in Barcelona, where the action is set.

Rodríguez Méndez's work is based on a true story of a man who led three lives. Lluiset, besides being a lawyer from a respectable family and an anarchist, as Flor de Otoño is a drag artist who performs in the decadent environment of a cabaret on the Paralelo during the time of Primo de Rivera. A significant aspect of stage and film versions of Flor de Otoño are scenes in the cabaret that highlight the artist's performances. In addition to the performances, Flor de Otoño uses metatheatrical techniques not only to highlight the characters' tendency to play roles within their roles, but also to reflect the hypocrisy of the society in which they live.

Gómez correctly observes that a good film adaptation of a play must "aprovechar al máximo la riqueza de posibilidades del medio cinematográfico" (Gómez, 2000, 51). Linda Seger has provided a practical guide on how that goal may be accomplished. In choosing a play for film adaptation, she recommends finding a realistic context that can be opened up, a story line that can be developed, and cinematic images to give expression to the human themes (Seger, 1992, 42). As we shall see, Rodríguez Méndez's Flor de Otoño lends itself admirably to that task.
Although movie adaptations of plays may deviate widely (one might even say wildly) from their source texts, there are many examples of careful fidelity. Gimferrer speaks of "fidelidades estériles" and "infidelidades (y aun traiciones) fecundas" (Gimferrer, 2005, 67); nevertheless, respectful fidelity to an important, well-written text, does not necessarily yield a mediocre film. For example, in recent years, Ventura Pons has produced admired, faithful versions of plays by Sergi Belbel and Josep Maria Benet i Jornet (Zatlin, 2007).

Such fidelity may prove problematic when spectators, critics, or the author himself begins to compare the movie with the stage production. Garcia-Abad has pointed out the particular challenge faced by Mario Camus in creating his 1987 film version of García Lorca's La casa de Bernarda Alba (filmscript by Mario Camus and Antonio Larreta). This "adaptación extremadamente respetuosa" (García-Abad, $2001,5)$ of a classic was a box-office hit but was rejected by many critics. Garcia-Abad reminds us that chronologically the movie closely followed José Carlos Plaza's successful, realistic stage production. No doubt the movie evoked that staging, "de la que no se puede desvincular y con la que, sin duda, guarda un parecido nada circunstancial" (Garcia-Abad, 2001, 6). Another case in point is Las bicicletas son para el verano (dir. Jaime Chávarri, 1984). Chávarri is certainly respectful of Fernando Fernán-Gómez's prize-winning text, which achieved a triumphant staging under Plaza's direction in 1982. Still Juan Antonio Ríos Carratalá labels Chávarri's adaptation as polemical. The movie was received enthusiastically by audiences and critics; Fernán-Gómez was less favorably impressed. He objected to the director's decision to make the dining room of his principal characters less central by moving some action to the outside (Ríos Carratalá, 1999, 160).

It is unlikely that spectators who saw both the play and the film would be concerned about having Fernán-Gómez's dialogue in the early sequences rendered faithfully but delivered in walks outside rather than at the dining room table. A standard technique in translating a stage play into a movie is precisely that kind of opening up to realistic space, including shifting of interior scenes to the outside. Gimferrer's opinion that it is a mistake to do so (Gimferrer, $2005,108)$ thus runs counter to much of film history. He clarifies that it is "el trabajo en el espacio fílmico, en el interior del encuadre, y no la naturaleza de lo que aparece 
en él, la verdadera piedra de toque para determinar si el espectador se halla ante un producto cinematográficamente genuino" (Gimferrer, 2005, 108). Significant aspects of a genuinely cinematographic transformation are "la planificación, la dirección de actores y el tratamiento del espacio" (Gimferrer, 2005, 109). The director of Un hombre Ilamado Flor de Otoño undoubtedly concentrates on these aspects but also moves much of the action outside.

Director Pedro Olea is well known for his acclaimed film adaptations of novels, including works by Pérez Galdós, Pérez-Reverte, and Antonio Gala. He affirms that he remains faithful to his source texts (Olea, 2008). Perhaps that is true of the novels, but quite counter to Rodríguez Méndez's opinion of the film version of Flor de Otoño. The playwright feels that the director did the movie "a su manera", however he pleased, and recalls, "Pedro se enfadó conmigo" (Rodríguez Méndez, 2008).

When I first analyzed Flor de Otoño as a play (Zatlin, 1992), I was unfamiliar with the film adaptation but fully aware of the controversy surrounding its stage premiere (1982, dir. Antonio Díaz Zamora; sets, costumes and lighting designed by Carlos Cytrinowsky). Rodriguez Méndez's text is highly cinematographic, that is, a reflection of the intense relationship between contemporary theatre and film that Hueso mentions. Quite opposite to the static condition often associated with realistic theatre, Flor de Otoño "requires spacial fluidity and visual effects associated with film" (Zatlin, 1992, 309). I posited that negative response to Díaz Zamora's "espectáculo" at the Teatro Español resulted because of the play's cinematic quality and obvious intertextuality with film. At some point, I also conjectured that perhaps the existence of the movie might have triggered a kind of over reaction on the part of critics.

Rejecting any dichotomy between "teatro" and "espectáculo," José Monleón sprang to the defense of Díaz Zamora's visual production on the general principle of what constitutes "la naturaleza del teatro" (Monleón, 1982, 21). He evoked Brecht and Valle-Inclán in defining the merits of Rodríguez Méndez's text and this particular staging (Monleón, 1982, 24). He praised the director for his "unidad de estilo y su fuerte teatralidad" and the designer for a series of elements that gave the production "esa sensorialidad vital y transgresora, ese espesor visual que conforma la teatralidad" (Monleón, 1982, 26).
Knowing that the playwright was not pleased with Olea's film version, in 2008 I asked him which of the stage productions of his play he considered most effective. He eschewed both of the major Madrid stagings (Teatro Español, 1982; María Guerrero, dir. Ignacio García, 2005). The latter revival, with film actor Fele Martínez in the title role, was faithful to Rodríguez Méndez's text. The author, observing that the director had neither added nor taken anything away from the original script, found that kind of fidelity to be exceptional (Rodríguez Méndez, 2005). Moreover, the revival at the Centro Dramático Nacional had spared no expense. Nevertheless, Rodríguez Méndez preferred a more modest Barcelona production that opened in November 2003. Directed by Josep Costa at the fringe Sala Artenbrut, with Jordi Llordella as Flor de Otoño, that staging was done without sets and with a dozen actors doubling in the 47 roles (Huertas Clavería, 2004, 1-2). Quite opposite to cinematic realism, Costa's production was highly theatricalist. The author's satisfaction with that staging approach may explain in part his lack of enthusiasm for the earlier film version, but he also specifically mentions the superlative lighting and, in positive terms, notes that in Barcelona the bilingual cast retained his intentional use of Catalan for some of the dialogue (Rodríguez Méndez, 2008). In Olea's movie, the use of Catalan has totally disappeared although a Spanish audience might have understood it. Despite the problems posed by Catalan dialogue for an American audience, Marion P. Holt managed to retain some hint of bilingualism in his English translation (Zatlin, 2005, 117-19).

Pedro Olea read Flor de Otoño in Primer Acto and contacted Rodríguez Méndez about his movie project. He proceeded to prepare a script with Rafael Azcona, a screenwriter of such importance that his death in April 2008 was noted in "Milestones" of the American news magazine Time, which proclaimed him to be "one of Spain's greatest cinematic talents". That praise echoes the assessment given some dozen years earlier by Ríos Carratalá: "En un cine como el español donde el papel de los guionistas apenas ha sido valorado, sólo un nombre es reconocido por la mayoría como maestro en ese campo: Rafael Azcona" (Ríos Carratalá, 1996, 49). For his performance in the title role of Un hombre Ilamado Flor de Otoño, José Sacristán was awarded the best actor prize at the San Sebastián film festival. There is no question that the movie was a success, but there is also no question that it deviated widely from the source text. Recalling Hernández Les's statement, one

ARBOR Vol. 187748 marzo-abril [2011] 337-343 ISSN: 0210-1963 
might say that Olea adapted the story, as if the text were a novel, rather than "una forma de expresión" as cinema tends to do with theatre (Hernández Les, 2005, 130); virtually none of the dialogue is retained and even the story has been altered significantly.

In English-language film studies, two oft-quoted theorists on adaptation, primarily of novels, are Geoffrey Wagner and Dudley Andrew. Wagner, basing himself on a thesis of Béla Balázs, developed categories he called analogy, transposition, and commentary. Andrew's taxonomy arrives at related conclusions but uses the terms borrowing, intersection, and fidelity of transformation. For Wagner, analogy represents a "considerable departure for the sake of making another work of art" (Wagner, 1975, 227); Andrew's corresponding term is borrowing, which takes an existing work and deals with it in a "vast and airy" way (Andrew, 1984, 99). Both theorists offer the option, which they consider in general to be less effective, of carrying the source text over to the screen unchanged: transposition and intersection, respectively. Canned theatre, that is, the filming of a stage production, would readily fit into this option.

Where the two theorists deviate most is in their third categories: Wagner's commentary and Andrew's transformation. In commentary, "an original is taken and either purposely or inadvertently altered in some respect. It could also be called a re-emphasis or re-structure" (Wagner, 1975, 222). Wagner believes that an authentic reconstruction could be a creative restoration; we might see this category as an inspired combination of Gimferrer's "fidelidades estériles" and "infidelidades fecundas". Andrew's term equates more directly with fidelity, although he allows for changes in the translation from literary text to film language. A transformation keeps the skeletal story while also finding stylistic equivalents in film for "the original's tone, values, imagery, and rhythm" (Andrew, 1984, 100). While Olea's adaptation of Flor de Otoño might be analyzed along the lines of Wagner's commentary as restructuring, it is distanced enough from Andrew's concept of transformation to fall instead within the latter's category of borrowing (or Wagner's analogy). Certainly a "vast and airy" departure is the focus of Rodríguez Méndez's negative reaction to the movie. Olea borrowed the title character and some skeletal elements but then restructured with substantial changes.
When the Asociación de Autores de Teatro published Rodríguez Méndez's selected theatre, Josep Sirera prepared the prologue to Flor de Otoño. In his illuminating discussion, Sirera tends to emphasize the very aspects of the play that disappeared in Olea's film. In particular, he praises the choice of historical background (1930 and the attack on the Cooperativa Obrera in the Barcelona neighborhood of Poble Nou) and the elaboration of linguistic diversity: "En la época (...) los representantes de la burguesía catalana se expresaban habitualmente entre ellos en catalán, lo que obliga al autor a hacer auténticos juegos malabares para no romper la verosimilitud sin impedir la comprensión correcta (...) de los que no conocen dicha lengua" (Sirera, $2005,100)$. Sirera affirms that the playwright is also precise in the use of Castilian, which is formal and correct when spoken by the upper classes and popular, with errors, in the lively speech of immigrants from Murcia and Andalusia (Sirera, 2005, 101).

Olea bypasses these key aspects of "the original's tone, values, imagery, and rhythm," to use Andrew's terminology. The playwright is not alone in making such an observation. Gómez specifically criticizes the film's loss of the "interesante efecto que produce el bilingüismo" and of "algunos episodios sociohistóricos importantes, como el referente a la Cooperativa Obrera de Poble Nou" (Gómez, 2000, 44). In her comparison of play and film, Georgina Whittingham likewise specifically cites these two components but adds others.

Whittingham observes the elimination of the Brechtian use of newspaper headlines -headlines that reveal distorted rather than objective journalism- and of a comicgrotesque scene in which Flor de Otoño's companions steal guns from a barracks while the military men attempt to aid their wounded friend (Whittingham, 2002, 4). That scene is among many in the play that evoke Valle-Inclán's esperpento: "España estaba en un estado de desorden y tumulto. La obra teatral mantiene el tono paródico y cínico para retratar la nefasta condición del pais" (Whittingham, 2002, 7). Gone from the movie is the satiric, grotesque tone that permeates the original text, most notably in the stage directions. Maria Paz Yañez affirms that Olea has turned Rodríguez Méndez's anti-hero into a hero (Whittingham, 2002, 2). Whittingham agrees, pointing out that Azcona and Olea's script includes moments of nostalgia and provides explanations for the protagonist's behavior that are absent in the source. Gómez 
concludes, "La adaptación de Pedro Olea se recrea en una visión un tanto estereotipada del travestismo sin presentar una reflexión crítica sobre la historia (...). Se echa en falta, en resumidas cuentas, un mayor rigor en la contextualización del film" (Gomez, 2000, 44).

Given that Rodríguez Méndez's play had not yet been staged and that Primer Acto, where it was published, is a specialized theatre journal that would not have been read by many moviegoers, it is understandable that Olea did not feel constrained to follow the original script. Thus, among other changes, he altered the tone of the opening scene and eliminated the culminating moment of civil conflict from the play: the 1930 violent confrontation between anarchists and the authorities at the Cooperativa Obrera. Indeed, in the movie the protagonist is executed years before the event at the Cooperativa Obrera took place.

The play begins with an esperpentic scene in which the police invade the respectable home of Flor de Otoño's mother; Lluiset has been accused in a scandalous murder, and she calls a family council in which all of the relatives are presented satirically. The movie begins with outside views of Barcelona. Doña Nuria (Carmen Carbonell) and Lluiset (José Sacristan) are seen strolling around and in the Barcelona cathedral. The mother recalls fondly how much her young son had liked visiting the little pond inside the Cathedral. Antique cars in the streets establish the time period as being the 1920s; gunshots establish the political unrest. Olea has effectively introduced visual and sound elements but he has not done so by converting verbal elements of the source text. Instead he and Azcona pursue their own script.

The 1930 scene at the Cooperativa Obrera is rich with cinematic possibilities, but the film director created instead a moment in the 1920s when the anarchists plan to blow up a train on which Primo de Rivera would be traveling to Barcelona. To be sure, Olea uses that moment to full visual effect. His camera not only moves outside but travels along isolated country roads as the protagonist and his friends Ricard and Surroca repeatedly leave the city. They initially explore the terrain and determine how to steal the necessary explosives and place them on a railroad bridge; they return, to carry out the theft; and they make a trip at night to implement their plan. The theft includes the use of Flor de Otoño's skills as a drag artist; the guard for the explosives is lured away from his post in his voyeuristic desire to watch, at a distance, what he thinks is a rape scene. But it is also Lluiset's role-playing as a woman that leads the police, who know about his identity as Flor de Otoño and therefore suspect him of being the woman, to follow and capture him.

It is worth observing that the several trips to the site of the would-be terrorist act, two by day and one by night, would be unlikely in a stage play. Again the movie scriptwriters have gone off on an original, narrative path. They are replacing rather than amplifying crucial components of the source text.

Playwright José Luis Alonso de Santos has stated that in movies the action is what counts, but in theatre what underlies the action may be more important. He observes that spectators leaving a play may ask what did it mean, while movie audiences are more likely to ask what happened (Alonso de Santos, 1997, 82). Like light comedy, movies - particularly ones aimed at a popular audiencetend to have closed endings that provide ready answers about what happened. Serious drama, on the other hand, may leave enough matters unresolved to force the spectator to think.

In Rodriguez Méndez's playscript, aspects of Lluiset-Flor de Otoño's character are ambiguous; in Olea's film, as Whittingham noted, there are no such doubts. Even the execution of Lluiset and his two friends is more justifiable in the film than in the play. In the movie, the three men plot killing Primo de Rivera and have no regard for other potential victims on the train; they are acting as terrorists. In the play, the violence at the Cooperativa Obrera results from a comedy of errors; a civil guard inadvertently tosses a bomb that starts the fray. In the movie, at least for proponents of capital punishment, the punishment may fit the crime; in Rodríguez Méndez's play, it was a student, not Lluiset and his friends, who brought the bomb in the first place and they are used as scapegoats. As Sirera notes, the grotesque tone of the play continues in a priest's effort to convert the men, a farcical scene with "tintes esperpénticos dignos del mejor Valle-Inclán" (Sirera, $2005,102)$. The movie does not satirize the priest.

Gómez points out the greater challenge involved in transforming a play into a movie: "desde un punto de vista estructural, para convertir una acción dramática en una narración, 
se requieren cambios sustanciales que complican la labor del adaptador. Una buena adaptación no consiste en una reproducción mecánica de la pieza teatral en cuestión" (Gómez, $2000,51)$. In that process, we can anticipate that the director will introduce additional locations and characters. The audience will see rather than merely hear about people and situations that are mentioned in the source dialogue.

Gómez correctly observes, "La transposición de elementos dramáticos en sus equivalentes fílmicos (...) es un arte dinámico que implica recreación, no imitación" (Gómez, $2000,190)$. Olea implements that concept in the direction of free adaptation. He takes the story line and characters as inspiration for a vastly different work. Un hombre Ilamado Flor de Otoño shares little with Rodríguez Méndez's play beyond the drag artist's name. The result is a fascinating movie, but it is not a faithful transformation of the play's tone, values, imagery and rhythm. It is not surprising that Rodríguez Méndez has little enthusiasm for Olea's movie.

\section{BIBLIOGRAPHY}

Abel, L. (1963): Metatheatre. A New View of Dramatic Form. New York, Hill and Wang, 1963.

Alonso de Santos, J. L. (1997): "De la escritura dramática a la escritura cinematográfica", Cine y Literatura. Monographic issue incorporating papers from X Ciclo Escritores y Universidad, 7 November-5 December 1995, República de las Letras 54, pp. 77-82.

Andrew, D. (1984): Concepts in Film Theory, Oxford, Oxford University Press.

Garcia-Abad Garcia, M. ${ }^{a}$ Teresa (1997): "Dos estéticas en contacto: lo cinético y lo dramático", Revista de Literatura, 59.118 (July-December), pp. 465-81.

- (2001): "Una Bernarda de cine: Lorca del papel a la pantalla", Estreno, 27.2, pp. 4-7.

Gimferrer, P. (2005): Cine y literatura, Barcelona, Seix Barral.

Gómez, M. A. (2000): Del escenario a la pantalla: La adaptación cinematográfica del teatro español, Chapel Hill, North Carolina Studies in the Romance Languages and Literatures.

Hernández Les, J. A. (2005): Cine y literatura. Una metáfora visual, Madrid, Ediciones JC.

Recibido: 30 de octubre de 2008 Aceptado: 16 de marzo de 2009
Huertas Clavería, J. M. (2004): "Text d'autor: Amb motiu de l'estrena teatral de Flor de otoño, de José M. ${ }^{a}$ Rodríguez
Méndez" <http://www.e-barcelona. org/index.php? name $=$ News \&file $=$ article\&sid=2975>.

Hueso, Ángel Luis (2001): "El referente teatral en la evolución histórica del cine", Anales de la Literatura Española Contemporánea, 26.1, pp. 45-61.

"Milestones" (2008): Time, 21 April, p. 26.

Molina, J. (1981): "Interview with Carla Matteini", Pipirijaina, 18, pp. 28-31.

Monleón, J. (1982): "El teatro es espectáculo. Defensa de Antonio Díaz Zamora y de su Flor de Otoño", Primer Acto, 196, pp. 21-26.

Olea, P. (2008): "Mesa redonda: El universo creador de Antonio Gala. Congreso Internacional Antonio Gala y El Arte de la Palabra", Córdoba, 3-5 March.

Ríos Carratalá, J. A. (1996): "Rafael Azcona, de la literatura al cine", in Relaciones entre el cine y la literatura: un lenguaje común, ed. J. A. Ríos Carratalá and J. D. Sanderson, Universidad de Alicante, Secretariado de Cultura, pp. 49-56.

Ríos Carratalá, J. A. (1999): El teatro en el cine español, Alicante, Instituto de Cultura Juan Gil Albert.

Rodríguez Méndez, J. M. (1995): Flor de Otoño, Madrid, Cátedra.

- (2005): Quoted in "En busca de una identidad". <http://www.elmundo.es/metropoli/2005/09/20/teatro/1127230824.html>. 
- (2008): "Telephone interview", 10 and 12 March.

Seger, L. (1992): The Art of Adaptation: Turning Fact and Fiction into Film, New York, Henry Holt.

Sirera, J. L. (2005): "Historia e historicismo" (prologue to Flor de Otoño), in José M. ${ }^{a}$ Rodríguez Méndez, Teatro escogido, Vol. 2, Madrid, AAT.

Un hombre llamado Flor de Otoño (1978): Dir. Pedro Olea. Screenplay by Rafael Azcona and Pedro Olea.
Wagner, G. (1975): The Novel and the Cinema, Cranford, NJ, Associated University Presses, Inc; London, The Tantivy Press. Whittingham, G. J. (2002): "Flor de Otoño de Rodríguez Méndez: la obra dramática, la adaptación fílmica y el enigma del protagonista", Paper read at Estreno international symposium, El próximo acto: Teatro español en el Siglo XXI, April.

Zatlin, P. (1992): "Cinema in Theatre: Examples from the Contemporary Spanish
Stage." Yearbook of Interdisciplinary Studies in the Fine Arts 3, pp. 305-313.

- (2005): Theatrical Translation and Film Adaptation. A Practitioner's View, Multilingual Matters.

- (2007): "From Stage to Screen: The Adaptations of Ventura Pons", Contemporary Theatre Review. Special issue Catalan Theatre 1975-2006: Politics, Identity and Performance, ed. Maria M. Delgado, David George and Lourdes Orozco. 17.3, pp. 434-45. 